\title{
BUDAYA KEAGAMAAN ARAB MELAYU SEBERANG KOTA JAMBI
}

\author{
RELIGIOUS CULTURE ARAB MELAYU SEBERANG OF \\ JAMBI CITY
}

\author{
Ari Yuda Kusuma, Aman \\ Universitas Negeri Yogyakarta, Indonesia \\ Ariyudakusumaa@gmail.com
}

DOI: $10.31291 /$ jlk.v19i1.899

Diterima: 16 Februari 2021; Direvisi: 22 Juni 2021; Diterbitkan: 30 Juni 2021

\begin{abstract}
This article aims to describe the forms and values in the Malay Arab religious culture Seberang of Jambi City. The ethnographic method with a realist ethnographic approach is used to describe the forms and values in the Malay Arab religious culture Seberang Jambi City without any influence from observers. This article was written objectively from the results of participant observations, interviews, and literature studies conducted in the Seberang area of Jambi City. The form of Arab Malay culture Across Jambi City obtained in this article is in the form of Assyura commemoration activities, Nisfu Syaban celebrations, Burdah, Nginau, Nuak Ketan, Nyukur babies, Pilgrimage to the Grave, Gambus, Zapin dance, Dana Syarah, and Hadrah dances. The values contained in the Malay Arab religious culture Seberang Jambi City consist of cultural values, religious values, character values, family values, and artistic values. Knowing the forms and values of Malay Arab religious culture across Jambi City can make the public know about the culture that exists in Jambi Province.
\end{abstract}

Keywords: Religious Culture, Arab Melayu, Seberang of Jambi City

\section{ABSTRAK}

Artikel ini bertujuan untuk mendeskripsikan wujud dan nilai-nilai dalam budaya keagamaan Arab Melayu Seberang Kota Jambi. Metode etnografi dengan pendekatan etnografi realis digunakan untuk mendeskripsikan 
wujud dan nilai-nilai dalam budaya keagamaan Arab Melayu Seberang Kota Jambi tanpa ada pengaruh dari pengamat. Artikel ini ditulis secara objektif dari hasil observasi partisipan, wawancara dan studi literatur yang dilakukan pada kawasan Seberang Kota Jambi. Wujud budaya Arab Melayu Seberang Kota Jambi yang didapat dalam artikel ini berbentuk kegiatan peringatan Assyura, perayaaan Nisfu Syaban, Burdah, Nginau, Nuak Ketan, Nyukur bayi, Ziarah Kubur, Gambus, tari Zapin, tari Dana Syarah dan Hadrah. Nilai-nilai yang terdapat dalam budaya keagamaan Arab Melayu Seberang Kota Jambi terdiri dari nilai budaya, nilai agama, nilai karakter, nilai kekeluargaan dan nilai seni. Dengan dikenalnya wujud dan nila-nilai budaya keagamaan Arab Melayu Seberang Kota Jambi dapat membuat khalayak ramai mengetahui tentang budaya yang ada di Provinsi Jambi.

Kata Kunci : Budaya Keagamaan, Arab Melayu, Seberang Kota Jambi

\section{PENDAHULUAN}

Indonesia sebagai negara kepulauan terbesar yang ada di dunia memiliki keanekaragaman suku, bahasa, agama dan budaya. Keanekaragaman ini menjadi aset yang tak ternilai harganya. Setiap wilayah memiliki budaya yang berbeda namun tetap menjadi kesatuan dalam kebudayaan nasional. Budaya daerah menjadi unsur yang penting dalam membangun kehidupan bangsa Indonesia, karena budaya daerah tersebut merupakan bagian jati diri bangsa. Budaya Arab Melayu Seberang Kota Jambi merupakan salah satu budaya daerah yang terdapat di Indonesia. Budaya ini berkembang pada masyarakat Seberang Kota Jambi yang berada di Kota Jambi, Provinsi Jambi.

Kota Jambi adalah ibukota dari Provinsi Jambi yang merupakan salah satu Kotamadya yang ada di Provinsi Jambi. Provinsi Jambi memiliki 2 Kotamadya dan 9 kabupaten. Secara geografis Kota Jambi terletak antara $00.45^{\circ}$ Lintang Utara $02.45^{\circ}$ Lintang Selatan, $101,10^{\circ}$ Bujur Timur. Seberang Kota Jambi merupakan sebuah kawasan tertua di Kota Jambi yang terletak di wilayah keluarahan Pelayangan dan Danau Teluk Kota Jambi.

Letak kawasan ini berada di pusat Kota Jambi pada bagian sisi utara sungai Batanghari. Pada bagian sisi selatan sungai Batanghari merupakan kawasan strategis ekonomi Jambi. Pada sisi selatan ini terdapat rumah dinas Gubernur Jambi, komplek 
perkantoran, komplek toko perdagangan dan pasar Angso Duo. Pasar Angso Duo ini adalah pasar terbesar yang ada di Jambi, yang juga menjadi urat nadi perdagangan di Jambi.

Kawasan Seberang Kota Jambi merupakan gambaran daerah kota lama Jambi atau kota Jambi sebelum berpindah ke sisi selatan sungai Batanghari. Disini hidup dan berkembang masyarakat asli Jambi yang menganut budaya keagamaan Arab Melayu. Budaya Arab Melayu merupakan hasil perpaduan budaya yang dibawa oleh pendagang (Arab) dan masyarakat setempat (Melayu).

Masyarakat Seberang Kota Jambi merupakan keturunan Arab yang bercampur dengan pribumi Melayu melalui pernikahan. ${ }^{1}$ Di masa lalu banyak para pedagang dari Arab yang melakukan perdagang di kawasan ini. Hasil interaksi yang terus berlangsung menjadi wadah saling mempelajari budaya hingga menghasilkan budaya keagaaman Arab Melayu Seberang Kota Jambi. Penamaan budaya Arab Melayu berdasarkan asal dari budaya ini yakni Arab dan Melayu.

Budaya keagamaan Arab Melayu Seberang Kota Jambi ialah berbentuk berbagai kegiatan masyarakat seperti kegiatan peringatan Assyura, perayaaan Nisfu Sya'ban, Burdah, Nginau, Nuak Ketan, Nyukur bayi, Ziarah Kubur, Gambus, tari Zapin, tari Dana Syarah dan Hadrah. Budaya keagamaan Arab Melayu ini memuat nilai-nilai yang terkandung dalam setiap kegiatan yang dilaksanakan. Hal yang penting pada budaya keagamaan Arab Melayu Seberang Kota Jambi ini adalah masih dilestarikan oleh masyarakat.

Kebudayaan atau budaya adalah kumpulan dari ilmu pengetahuan, adat istiadat, tradisi dan perilaku sehari-hari yang terdapat pada suatu masyarakat. ${ }^{2}$ Kebudayaan mengandung unsurunsur yang menjadi syarat agar dapat dinyatakan sebuah kebudayaan diantaranya memiliki sistem bahasa, sistem pengetahuan,

${ }^{1}$ Lilis Suciandi, "Peranan Arab Melayu Dalam Pengembangan Islam Di Kota Jambi Awal Abad XX" Vol 3 No 2 September 2019 (September 2, 2019): 87.

${ }^{2}$ Ryan and Endang, "Pergeseran Nila-nilai Budaya Pada Suku Bonai Darussalam Kabupaten Rokan Hulu Provinsi Riau” 23, no. 1 (2016): 19. 
sistem sosial, sistem peralatan hidup dan teknologi, sistem mata pencaharian hidup, sistem religi dan kesenian. ${ }^{3}$

Budaya keagamaan Arab Melayu Seberang Kota Jambi sebagai sebuah budaya, memiliki unsur-unsur seperti yang telah dijelaskan di atas. Budaya keagamaan Arab Melayu Seberang Kota Jambi memuat sistem bahasa, sistem pengetahuan, sistem sosial, sistem peralatan hidup dan teknologi, sistem mata pencaharian hidup, sistem religi dan kesenian dalam kehidupan masyarakatanya. Budaya keagamaan Arab Melayu Jambi lebih merujuk kepada konsep budaya immateril dengan hasil penerapan yang berbentuk tindakan, kebiasaan dan perbuatan masyarakat. Hasil dari budaya immaterial sendiri dapat berupa tradisi, kesusateraan, sistem penanggalan, dongeng ataupun hasil kebudayaan lainnya. ${ }^{4}$

Wujud dan nilai-nilai budaya keagamaan Arab Melayu Seberang Kota Jambi sebagai sebuah kebudayaan masih belum banyak diketahui oleh khalayak ramai. Padahal budaya keagamaan Arab Melayu Seberang Kota Jambi banyak mempraktikkan kegiatan agama yang dibalut dengan budaya. Budaya kegamaan Arab Melayu Seberang Kota Jambi juga menjadi acuan dalam perilaku keagamaan yang ada disana.

Perilaku keagamaan ini pada awalnya hanya dilakukan pada masyarakat tertentu. Namun, seiring dengan bergulirnya waktu, budaya keagamaan Arab Melayu Jambi mengalami penyesuain dengan perkembangan zaman. Banyak kegiatan yang diseusaikan dengan keadaan dan kebutuhan yang ada di masyarakat. Hal ini turut mempengaruhi keberadaan budaya keagamaan Arab Melayu Seberang Kota Jambi dalam kehidupan masyarakat.

Berdasarkan hal-hal tersebut, sangat menarik untuk mengungkap dan menggali wujud dan nilai-nilai budaya keagamaan Arab Melayu Seberang Kota Jambi ini. Oleh karena

${ }^{3}$ Tasmuji, Ilmu Alamiah Dasar, Ilmu Sosial Dasar, Ilmu Budaya Dasar, 2011th ed. (Surabaya: IAIN Sunan Ampel Press, n.d.), 65.

${ }^{4}$ Alfain Nur Mustawhisin, Rully Putri Nirmala Puji, and Wiwin Hartanto, "Sejarah Kebudayaan: Hasil Budaya Material Dan Non Material Akibat Adanya Pengaruh Islam Di Nusantara," Bakaba: Jurnal Sejarah Kebudayaan Dan Kependidikan 8 (June 2019): 34. 
itu, Informasi yang diperoleh tentang wujud dan nilai-nilai budaya keagamaan Arab Melayu Seberang Kota Jambi dapat diketahui oleh khalayak ramai dan tidak terbatas pada masyarakat Jambi semata. Artikel ini akan mengungkapkan dan menjelaskan asal mula berkembangnya budaya keagamaan Arab Melayu Seberang Kota Jambi, kehidupan sosial ekonomi masyarakatnya, wujud tradisi dan seni serta nilai-nilai yang terkandung dalam budayanya.

Metode yang digunakan dalam artikel ini adalah metode etnografi dengan pendekatan etnografi realis. Etnografi realis mendeskripsikan suatu fenomena kebudayaan tanpa ada pengaruh dari pengamat. Artikel ini ditulis secara objektif dari hasil observasi partisipan, wawancara dan studi literatur yang dilakukan pada kawasan Seberang Kota Jambi. Metode etnografi sendiri merupakan sebuah deskripsi kebudayaan etnik dari sebuah suku bangsa secara keseluruhan. ${ }^{5}$ Inti dari etnografi adalah upaya untuk memperhatikan makna-makna tindakan dari kejadian yang menimpa orang yang ingin kita pahami. ${ }^{6}$ Etnografi juga menjadi sebuah metode yang menjelaskan secara tersurat tentang kegiatan sosial, perkumpulan sosial, ciri dan asal suatu komunitas manusia. ${ }^{7}$ Metode etnografi yang digunakan ini bertujuan untuk meneliti kondisi objek alamiah yang difokuskan pada budaya keagamaan Arab Melayu yang terdapat di masyarakat Seberang Kota Jambi dengan mengobservasi pola perilaku, adat istiadat dan pandangan hidupnya melalui penghayatan serta penelitian pada objek yang diteliti.

${ }^{5}$ Koentjaraningrat, Pengantar Antropologi II, 1998th ed. (Jakarta: Rineka Cipta, n.d.), 1.

${ }^{6}$ Spradley James, Metode Etnografi, 2007th ed. (Yogyakarta, n.d.), 5.

${ }^{7}$ Kamarusdiana, "Studi Etnografi Dalam Kerangka Masyarakat Dan Budaya," Salam : Jurnal Sosial dan Budaya Syar-i 6, no. 2 (March 22, 2019): 28, http://journal.uinjkt.ac.id/index.php/salam/article/view/10975. 


\section{HASIL DAN PEMBAHASAN}

\section{Berkembangnya Budaya Keagamaan}

\section{Arab Melayu Seberang Kota Jambi}

Budaya Keagamaan Arab Melayu Seberang Kota Jambi merupakan sebuah budaya yang terdapat pada masyarakat Seberang Kota Jambi. Budaya ini telah menjadi pola perilaku dari kehidupan masyarakat setempat. Diketahui Islam mulai masuk dan menyebar ke wilayah Jambi pada abad ke-15 M. Sejarah tentang masuknya Islam ke Jambi diketahui secara fragmentasi, dimana penyebaran dan perkembangan Islam di Jambi identik dengan peradaban budaya Melayu Jambi. ${ }^{8}$ Pembawanya adalah seorang saudagar dari Turki bernama Ahmad Salim yang juga dikenal dengan sebutan Datuk Paduko Berhala. Selanjutnya Ahmad Salim menikah dengan seorang putri keturunan dari Paguruyung yang bernama putri Selaras Pinang Masak. Masuk dan berkembangnnya Islam di Jambi setelah Ahmad Salim menikah dengan Putri Selaras Pinang Masak. ${ }^{9}$

Perkembangan Islam di Jambi selanjutnya diketahui dari kerajaan Melayu hingga masa kesulatan Jambi. Kerajaan Melayu mulai dikenali sejak ekspedisi Pamalayu oleh kerajaan Singosari sekitar tahun 1275 M. Kemudian dengan pengiriman arca Amoghapasa oleh Kertananegara (raja Singosari sekitar tahun 1286 M kepada raja Melayu, Dhamasraya, Malayapura, dan Pagaruyung.

Kerajaan Melayu yang menjadi salah satu kerajaan yang ada di wilayah Semenanjung Malaka ikut serta mendominasi jalur perekonomian penting di pantai Timur yang berhubungan dengan Persia, India, Gujarat, Cina, Arab dan wilayah Nusantara ini. Hubungan yang terjalin dengan dunia luar menghasilkan dampak kemajuan di bidang ekonomi perniagaan, budaya dan agama Islam.

${ }^{8}$ Katalog, Museum Gentala Arasy, 2019th ed. (Jambi: Pemeritahan Provinsi Jambi Dinas Kebudayaan dan Pariwisata Museum Sigenjai, n.d.), 6.

${ }^{9}$ Poesponegoro, Sejarah Nasional Indonesia: Zaman Pertumbuhan Dan Perkembangan Kerajaan Islam Di Indonesia., 1990th ed. (Jakarta: Balai Pustaka, n.d.), 43. 
Penyebaran agama Islam yang dilakukan dapat berjalan dengan damai, sehingga tidak heran bila Islam berkembang dengan pesat di wilayah Jambi. Penyebaran agama Islam terus berlanjut yang dipelopori oleh Ulama, Mubaligh dan Kiai yang pergi ke Mekah Al-Mukaramah untuk belajar. Hal ini turut memiliki peran besar dalam menyebarkan dan mengembangkan Islam di Jambi. ${ }^{10}$

Pada masa kesultanan Jambi terdapat sebuah kawasan yang menjadi pusat dari perdagangan bernama Seberang Kota Jambi. Kawasan ini menjadi wilayah ekonomi perniagaan yang ada di Jambi. Selain itu, kawasan ini juga menjadi tempat penyebaran budaya dan agama Islam. Seiring dengan waktu, seberang Kota Jambi telah menjadi kawasan yang membentuk sebuah peradabannya dengan kebudayaannya sendiri.

Proses interaksi antara penduduk asli Melayu Seberang Kota Jambi dengan para pedagang yang berasal dari Arab khususnya menyebabkan terjadi percampuran budaya. Hingga menghasilkan suatu kebudayaan baru, yang bernama budaya keaagamaan Arab Melayu Seberang Kota Jambi. Selanjutnya, Kebudayaan keagamaan Arab Melayu terus melekat pada setiap sendisendi kehidupan Masyarakat Seberang Kota Jambi.

Kuatnya pengaruh Islam di Seberang Kota Jambi juga telah banyak menumbuhkan pesantren. Ada pesantren yang telah berdiri sejak awal abad ke-20 M. Pesantren-pesantren ini dipelopori oleh tokoh-tokoh dari perkumpulan Perukunan Tsamaratul Insan, sebuah organisasi kemasyarakatan oleh para ulama Jambi yang diresmikan oleh Residen Negeri Jambi No. 1336 pada tanggal 10 September $1915 .^{11}$

Pesantren tersebut terdiri dari pesantren Nurul Islam yang didirikan oleh K.H.M. Saleh tahun 1922 di Tanjung Johor, pesantren Nurul Iman yang didirikan oleh H. Ibrahim bin H. A. Majid tahun 1915 di Kampung Tengah, pesantren Aljauharen didirikan oleh H.A. Majid di Tanjung Johor tahun 1922 dan

\footnotetext{
${ }^{10}$ Katalog, Museum Gentala Arasy, 6-7.

${ }^{11}$ Siti Mariah Ulfah, "Perukunan Tsamaratul Insan Dan Perannya dalam Menghadapi Perubahan Sosial Budaya Di Provinsi Jambi," Buletin Al-Turas 26 (January 2020): 138.
} 
pesantren Saadatur Daren yang didirikan oleh H.A Syukur tahun 1915 di Tahtul Yaman. Bagi masyarakat Seberang Kota Jambi, pendidikan merupakan sarana yang memiliki tujuan mencerdaskan kehidupan bangsa dan negara supaya menuju pencerahan. ${ }^{12}$ Sehingga Seberang Kota Jambi juga dikenal sebagai kota santri dan Serambi Mekah-nya Jambi.

\section{Kehidupan Sosial Ekonomi Seberang Kota Jambi}

Pada masa sekarang, kawasan Seberang Kota Jambi menjadi sebuah kawasan lama di Kota Jambi, yang terletak pada bagian utara dipisahkan oleh sungai Batanghari. Wilayah administrasi Seberang Kota Jambi meliputi kecamatan Pelayangan dan Danau Teluk. Kecamatan Pelayangan memiliki luas 15,29 $\mathrm{km}$ yang terdiri dari 6 kelurahan dengan jumlah penduduk 12.396 jiwa. Sedangkan wilayah kecamatan Danau Teluk memiliki luas $15.70 \mathrm{~km}$ yang terdiri dari 5 kelurahan dengan jumlah penduduk kecamatan Danau Teluk 12.079 jiwa

Seberang Kota Jambi memiliki kehidupan penduduk yang sangat bersahaja dan kental dengan nuansa Islamnya. Masyarakat yang mendiami kawasan ini selalu memegang erat setiap ajaran Islam. Islam menjadikan kehidupan manusia tenang dan damai apabila mengikuti setiap ajarannya. Hal inilah yang dijalankan oleh masyarakat Seberang Kota Jambi. Kondisi ini menjadikan Seberang Kota Jambi menjadi kawasan yang tenang dan damai untuk ditempati.

Mata pencaharian penduduk Seberang Kota Jambi umumnya adalah sebagai petani dan nelayan. Selain itu, terdapat juga sebagian masyarakat yang bekerja pada sektor industri rumah tangga seperti memproduksi tepek ikan, kerupuk ikan, kerajinan tangan dan batik. Kawasan ini juga terkenal sebagai daerah pembuat ketek dan speedboat yang berada di bagian kampung Arab Melayu dan Tahtul Yaman. Kemudian ada juga yang bekerja di sektor industri kayu, pengolahan karet, tukang ojek motor, tukang perahu ketek dan buruh pabrik.

Olahan makanan kerupuk ikan yang terkenal dari Seberang Kota Jambi adalah kerupuk ikan panggang. Kerupuk ikan pang-

${ }^{12}$ Katalog, Museum Gentala Arasy, 33. 
gang merupakan industri rumah tangga yang ada di Seberang Kota Jambi yang dijalankan oleh masyarakat. Industri rumah tangga ini menjadi salah satu sumber penghasilan tambahan bagi masyarakat Seberang Kota Jambi. Selain kerupuk ikan panggang, industri rumah tangga di daerah ini yang dapat memberikan penghasilan tambahan adalah kerajinan tangan seperti miniatur kapal, batik, dan kaligrafi.

Hasil industri rumah tangga ini dipasarkan di sanggar batik yang ada di kelurahan Arab Melayu Seberang Kota Jambi selain sebagai tempat menjual batik. Pada sanggar ini terdapat hasil olahan lainnya seperti asesoris wanita dan miniatur. Sanggar batik ini terletak tepat didepan perhentian ketek (sampan kecil) di kelurahan Arab Melayu. Hal ini membuat para wisatawan lokal dan wisatawan asing yang datang ke Seberang Kota Jambi bisa langsung membeli hasil industri rumah tangga ini.

Kehidupan sosial ekonomi Seberang Kota Jambi sangat sederhana apabila dibandingkan dengan Kota Jambi meskipun jaraknya hanya beberapa ratus meter dan hanya dipisahkan oleh sungai Batanghari. Seberang Kota Jambi masih menerapkan pola masyarakat pedeseaan asri dengan sungai yang menjadi tempat mata pencahariannya. Apabila memasuki kawasan Seberang Kota Jambi, akan terlihat nuansa tradisional yang menggambarkan bahwa masyarakat yang bermukim disana adalah masyarakat yang masih hidup dalam tradisi keagaaman. Di kawasan ini tidak terdapat gedung tinggi dan pusat perbelanjaan, yang ada hanya rumah-rumah panggung khas daerah Jambi, masjid, dan pondok pesantren.

Secara keseluruhan masyarakat Seberang Kota Jambi memeluk agama Islam dan hanya sebagaian kecil pendatang yang menganut agama lainnya. Secara keseluruhan kondisi masyarakat Seberang Kota Jambi bersifat majemuk dan heterogen. Pada masa pendudukan kolonial Belanda masyarakat Seberang Kota Jambi terdiri dari masyarakat Melayu Jambi, bangsa Eropa, Cina dan Arab. Kemudian pada saat sekarang masyarakat kawasan ini terdiri dari orang Arab Melayu, merupakan keturanan dari orang Arab dan Melayu yang menikah kemudian memiliki keturunan. Selanjutnya ada orang Jawa, Batak, Minang, Cina dan lain-lainnya. 


\section{Akulturasi Budaya Keagamaan Arab Melayu Masyarakat Seberang Kota Jambi}

Masyarakat Seberang Kota Jambi adalah orang-orang keturunan Arab yang bercampur dengan pribumi Melayu melalui pernikahan. ${ }^{13}$ Pada awalnya, Seberang Kota Jambi didiami oleh orang-orang Melayu yang berada di wilayah lintas perdagangan. Selanjutnya, kawasan ini mendapatkan pengaruh budaya dari banyak pedagang yang berasal daru berbagai negara seperti Cina, Persia, India dan Arab.

Kehadiran bangsa Cina, Persia, India dan Arab tersebut guna melakukan perdagangan serta menyebarkan agama Islam ke wilayah nusantara khususnya daerah Seberang Kota Jambi yang menjadi titik awal dari lahirnya kebudayaan Arab Melayu Seberang Kota Jambi. Pada saat itu, para pedagang Arab lebih gencar dalam melakukan perdagangan dan penyebaran pada kawasan ini.

Para pedagang Arab menggunakan komunikasi untuk bersosialisai dalam mengenal kehidupan masyarakat pribumi. Para pedagang dan masyarakat pribumi kemudian saling mempelajari bahasa dan budaya dari masing-masing asal mereka untuk memudahkan proses perdagangan dan penyeberan agama Islam. Hal ini juga bertujuan untuh memudahkan proses transformasi budaya antara para pedagang dan mayarakat pribumi.

Di sini tidak sedikit pedagang Muslim asing itu tinggal lama dan menikah dengan penduduk setempat. Semua itu merupakan cikal bakal berkembangnya komunitas Islam di Nusantara. Kegiatan perdagangan dan penyebaran Islam kemudian juga melibatkan penduduk pribumi, termasuk orang Melayu dan etniketnik pesisir lain yang meleuk agama Islam. Tradisi dagang (merantau untuk berniaga) lantas tumbuh di kalangan etnik pesisir ini. $^{14}$

13 "Peranan Arab Melayu Dalam Pengembangan Islam di Kota Jambi Awal Abad XX," 87.

${ }^{14}$ Khairul Huda, "Islam Melayu Dalam Pusaran Sejarah : Sebuah Transformasi Kebudayaan Melayu Nusantara," Toleransi: Media Komunikasi Umat Beragama 8, no. 1 (June 2016): 79. 
Dalam melaksanakan kegiatan tersebut, mereka telah banyak mewariskan berbagai bentuk peninggalan budaya yang bernuansa Islam dalam kehidupan. Budaya-budaya inilah yang nantinya akan menjadi budaya lokal setempat hasil dari perpaduan budaya pendatang dan pribumi. Hasil dari proses perpaduan antara para pedagang (Arab) dengan masyarakat setempat (Melayu) menghasilkan budaya baru yang dikenal dengan budaya keagamaan Arab Melayu Seberang Kota Jambi.

\section{Wujud Tradisi Budaya Keagamaan Arab Melayu Seberang Kota Jambi dalam Perilaku Keagamaan}

Perilaku keagamaan adalah tingkah laku yang didasarkan atas kesadaran tentang adanya Tuhan Yang Maha Esa dalam aktifitas keagamaan seperti shalat, zakat, puasa dan kegiatan lainnya. ${ }^{15}$ Perilaku menjadi tanggapan atau reaksi individu dan sekelompok orang terhadap rangsangan atau lingkungan. Sedangkan keagamaan berasal dari kata agama yang berarti sistem, prinsip kepercayaan terhadap Tuhan dengan ajaran kebaktian dan kewajiban bertalian dengan kepercayaan itu. ${ }^{16}$ Perilaku keagamaan masyarakat Seberang Kota Jambi sangat dipengaruhi oleh budaya Keagamaan Arab Melayu Seberang Kota Jambi.

Masyarakat Seberang Kota Jambi merupakan keturunan Arab yang bercampur dengan pribumi Melayu melalui pernikahan. ${ }^{17}$ Terdiri dari beberapa suku yakni suku Al Baragbah, Al Jufri, Al Idrus, Al Habsyi, Al Kap, Al Haddad Joban, Basyir dan Atik. Mereka adalah suku-suku yang berasal dari Hadramaut di Jazirah Arab. Umummnya mereka masih kuat mempertahankan nila-nilai kesukuannya sepeti menikah hanya dalam lingkungan suku.

Kelompok ini terbagi menjadi dua kelompok yakni Sayyid dan kelompok non-Sayyid. Kelompok Sayyid lebih tinggi kedudukannya di dalam masyarakat Arab Melayu dibandingakan ke-

${ }^{15}$ Mursa, Kamus Ilmu Jiwa Dan Pendidikan, 1980th ed. (Bandung: AlMa'arif, n.d.), 121.

${ }^{16}$ W.J.S. Poerwadarminta, Kamus Umum Bahasa Indonesia, 1991st ed. (Jakarta: PN Balai Pustaka, n.d.), 569.

17 "Peranan Arab Melayu dalam Pengembangan Islam di Kota Jambi Awal Abad XX," 87. 
lompok non-Sayyid dan pribumi. Sampai saat dini, kelompok Sayyid yang masih ada adalah keturunan Habib Husin Baragbah. Sedangkan dari kelompok non-Sayyid adalah suku Bafadhal yaitu Muhammad Sufi Bafadhal. ${ }^{18}$

Terlihat bahwa perilaku keagamaan masyarakat Seberang Kota Jambi mengikuti ajaran agama dan lingkungan. Menjadikan mereka memiliki kedudukan yang lebih tinggi dalam komunitas agama Islam yang ada di Jambi. Hal ini juga didasari kawasan Seberang Kota Jambi merupakan tempat dimana Islam pertama kali masuk ke Jambi. ${ }^{19}$ Selanjutnya diperkuat dengan banyaknya masyarakat Seberang Kota Jambi yang memiliki garis keturunan Hadramaut di Jazirah Arab.

Jazirah Arab merupakan wilayah lahirnya agama Islam, yang selanjutnya di sebarluaskan oleh Nabi Muhamad Saw. Masyarakat Jazirah Arab menjadi orang-orang yang pertama kali bersentuhan dan mengenal agama Islam. Kemudian mereka ikut berperan dalam menyebarkannya ke seluruh dunia hingga ke Indonesia dan Seberang Kota Jambi.

Dalam menjalani kehidupannya, masyarakat Seberang Kota Jambi memiliki banyak kegiatan tradisi budaya keagamaan Arab Melayu yang berdampingan dengan kesehariannya. Tradisi ini pada awalnya hanya dilakukan oleh masyarakat Seberang Kota Jambi dari kalangan Sayyid dan non-Sayyid. Tradisi ini secara tidak langsung memperlihatkan kedudukan masyarakat Seberang Kota Jambi dalam kehidupanya di antara masyarakat lainnya. Tradisi yang hanya bisa dilakukan masyarakat Seberang Kota Jambi menandakan bahwa kedudukan mereka berbeda dan mempunyai keunikan tersendiri, sehingga menjadi kebiasan masyarakatnya. Namun seiring dengan perkembangan tradisi ini telah dilakukan oleh semua masyarakat Seberang Kota Jambi.

Tradisi sendiri secara Epistemologi berasal dari bahasa latin (tradition) yang memiliki arti serupa dengan dengan budaya (culture) atau adat istiadat. ${ }^{20}$ Tradisi memiliki suatu bentuk

\footnotetext{
${ }^{18} 88$.

1988 .

${ }^{20}$ Djumransjah, HM, Pendidikan Islam Menggali "Tradisi” Mengu-
} kuhkan Eksistensi (Jakarta : P3M, 1998), 86. 
kegiatan yang dilaksanakan oleh suatu kelompok orang atau masyarakat secara terus menerus. ${ }^{21}$ Adapun tradisi budaya Keagamaan Arab Melayu Seberang Kota Jambi berjenis tradisi ritual agama yang berupa peringatan Assyura (Syuro), perayaaan Nisfu Syaban, Burdah, Nginau, Nuak Ketan, Nyukur bayi, Ziarah Kubur.

\section{Tradisi Budaya Hari Assyura}

Kegiatan ini dilestarikan oleh masyarakat seberang Kota Jambi secara turun temurun. Hari Assyura atau Syuro sendiri jatuh pada tanggal 10 Muharram. Dalam kegiatan ini masyarakat Seberang Kota Jambi dianjurkan untuk bersedekah, menyukur rambut, berkunjung ke rumah orang Tuo Tengganai dan berziarah kubur. Kegiatan ini hanya dapat ditemukan di Seberang Kota Jambi dan tidak terdapat di wilayah lain yang ada di Jambi. Sehingga kegiatan ini menjadi kepunyaan dari masyarakat Seberang Kota Jambi. Tujuan dari kegiatan ini adalah untuk menyambung silaturahmi dan menjauhkan dari segala macam bencana.

Hari Assyura adalah hari kesepuluh pada bulan Muharram dalam penanggalan Islam. Sedangkan Assyura sendiri berarti kesepuluh. Hari ini menjadi popular di tengah-tengah umat Islam. ${ }^{22}$ Pada tanggal 1 sampai 10 Muharram kita dianjurkan untuk berpuasa dan melakukan amal kebaikan. Hari Assyura menjadi hari yang sangat sangat bersejarah dan sangat mulia karena pada hari ini terjadi berbagai peristiwa besar yang umumnya dialami oleh para nabi pada zaman Dahulu. ${ }^{23}$

Pada hari Assyura ini masyarakat Seberang Kota Jambi juga memberikan santunan dan membuat bubur yang disebut dengan bubur Assyura. Kegiatan membuat bubur berawal dari ungkapan syukur atas berkah yang telah diberikan Allah Swt. Untuk mengungkapkan rasa syukur tersebut dibuatlah bubur untuk dibagikan kepada orang-orang yang membutuhkan. Bubur

${ }^{21}$ Rofiq Ainur, "Tradisi Slametan Jawa Dalam Perspektif Pendidikan Islam,” Jurnal Pendidikan Islam 15, no. 2 (September 2, 2019): 96.

${ }^{22}$ Ahmad Khairuddin, Asyura : Antara Doktrin, Historis Dan Antropologis Perspektif Dakwah Pencerahan, vol. 3, 5 (Jurnal Al-Hiwar, 2015), 1.

${ }^{23}$ Marfu'ah, Mengenal Hari-Hari Besar Islam, 2010th ed. (Semarang: Alprin, n.d.), 43. 
ini dibagikan lewat masjid kepada musafir, fakir miskin dan anak yatim. Sebelum membagikan bubur, terlebih dahulu dilakukan kegiatan mengaji, shalawatan dan doa. Selain kegiatan pembagian santunan dan bubur, di malam harinya dilakukan pembacaan Yasin dan Tahlil yang dimpin oleh ulama.

\section{Tradisi Budaya Perayaaan Nisfu Sya'ban}

Bulan Syaban adalah bulan yang mulia dan memiliki keajaiban. ${ }^{24}$ Masyarakat Seberang Kota Jambi meyakini Nisfu Sya'ban yang terdapat di bulan ini adalah malam yang istimewa. Kegiatan Nisfu Sya'ban yang dilakukan masyarakat Seberang Kota Jambi di masjid pada malam bulan Nisf Sya'ban tanggal 14 atau 15 sehabis shalat magrib. Pada malam itu masyarakat meyakini malaikat pencatat pahala dan dosa akan bertemu Allah SWT..

Peringatan Nisfu Sya'ban ini dilaksanakan guna mengingatkan masyarakat agar segera mengganti puasa yang batal pada ramadan tahun lalu karena sudah mulai mendekati bulan Ramadhan lagi. Pada saat perayaaan Nisfu Sya'ban masyarakat yang datang melafalkan surah Yasin, melantunkan doa dan berzikir. Mereka membawa air mineral yang nantinya akan diletakan di hadapan orang-orang yang sedang membaca surah Yasin dan doa-doa. Kemudian air mineral yang telah dibacakan surah Yasin dan doa dibawa kembali kerumah.

Kegiatan ini memiliki makna yang dalam bagi mayarakat Seberang Kota Jambi. Bagi masyarakat Seberang Kota Jambi kegiatan ini mengakrabkan tali silaturahmi dengan berkumpul bersama. Menjaga keharmonisann antar sesama anggota masyarakat. Menjaga ajaran agama Islam dengan melakukan kegiatan membaca Yasin dan doa-doa. Karena bagi mereka dengan memperingati Nisfu Sya'ban menjadikan kehidupan lebih dekat dengan sang pencipta. Kegiatan ini telah menjadi tradisi yang masyarakat Seberang Kota Jambi lakukan sejak dahulu. Berlangsung secara turun temurun antar generasi pada masyarakat Seberang Kota Jambi. Membawa berkah dan syafaat bagi keberlang-

${ }^{24}$ Zumratus, Menggapai Berkah Di Bulan-Bulan Hijriyah, 2015th ed. (Jakarta: Pustaka Al-Kautsar, n.d.), 5.u 
sungan hidup karena rasa syukur yang selalu dipanjatkan kehadiran Allah Swt..

\section{Tradisi Budaya Burdah}

Burdah adalah bacaan shalawat dan ucapan-ucapan puji syukur kepada Allah Swt. dan Nabi Muhammad Saw. secara bersama-sama oleh masyarakat Seberang Kota Jambi dengan arahan dari seeorang ulama. Burdah juga merupakan pembacaan doa untuk mengusir penyakit yang telah lama diderita oleh seseorang. Burdah dilaksanakan jika masyarakat Seberang Kota Jambi mengalami kondisi tertentu dan peristiwa aneh.

Burdah yang digunakan pada orang sakit dalam upaya pengobatan, biasanya dilakukan di rumah orang yang sakit dengan mengundang ulama dan tokoh masyarakat untuk bersama-sama membaca Burdah agar orang yang sakit segera sembuh. Burdah yang dibacakan pada saat terjadi bencana, dilaksanakan dengan cara berkeliling kampung dan masjid-masjid. Prosesi ini bertujuan agar bencana tersebut segera berakhir dan tidak datang kembali.

Kegiatan ini selain sebagai sarana untuk pengobatan tradisional, juga memuat makna bahwa semua yang terjadi pada kehidupan manusia hendaklah mengadu kepada Allah Swt. sebagai sang pencipta. Manusia yang hidup di dunia ini hanya bersifat sementara sehingga harus selalu mendekatkan diri kepada Allah Swt. agar membuat kehidupa manusia menjadi lebih berarti dan selalu terlindungi dari segala bahaya yang mengancam.

\section{Tradisi Budaya Makan Besamo}

Tradisi makan bersama memiliki kegunaan penting dalam membangun hubungan kebersamaan antar warga masyarakat. Dengan melakukan kegiatan ini, masyarakat dapat mempererat tali ikatan sosial secara personal dan kelompok. Kegiatan ini biasa dilaksanakan di berbagai acara seperti acara pernikahan, kendurian, sunatan dan ritual lainnya. Tradisi ini diselenggarakan untuk menandai kegiatan maupun acara adat yang biasanya telah tersedia makanan tradisional ciri khas masyarakat setempat. Tradisi makan bersama ini seringkali dilaksanakan di Masjid 
Ba'lawi yang merupakan Masjid tertua di kelurahan Arab Melayu.

Tradisi ini dilaksanakan setelah usai shalat Idul Fitri. Tradisi ini hanya dijalankan oleh kaum laki-laki dengan cara tradisional, dua sampai lima orang duduk melingkar satu nampan yang berisi makanan dan kemudian menyantapnya secara bersama-sama dengan menu andalannya kari. Kebiasaan ini menjadi simbol dari suatu hubungan kebersamaan masyarakat.

Kegiatan ini selain memupuk rasa kebersamaan dan kekeluargaan, juga menjadi sebuah pandangan hidup. Manusia hidup harus saling berdampingan dan saling membutuhkan sesamanya. Tidak ada manusia yang dapat hidup dan melakukan semuah kegiatannya dalam kesendirian. Semua manusia yang telah diciptakan Allah Swt. adalah sama dan mereka harus bekerja sama dalam mencapai tujuan hidupnya.

\section{Tradisi Budaya Nginau}

Nginau merupakan sebuah tradisi larangan atau pantangan yang terdapat di kawasan Seberang Kota Jambi. Tradsi ini menjadi sebuah bentuk perlindungan dari orang tua untuk anaknya. Mereka percaya pembelajaran kepada anak dimulai sejak masih berada dalam kandungan atau ketika anak masih dalam bentuk janin. Dalam tradisi Nginau terdapat larangan yang harus di ikuti oleh orang tua seperti larangan ribut, melakukan tindakan kasar, mengeluarkan kata kotor dan mengkonsumsi yang diperoleh melalui cara haram.

Pada calon ibu yang sedang hamil memiliki pantangan tersendiri, dilarang menghina, mengejek atau mencela orang-orang yang memiliki cacat fisik karena dipercaya apa yang dikatakan oleh sang ibu akan terjadi pada anaknya ketika lahir kelak. Hal di atas menjelaskan Nginau merupakan tradisi yang menjaga para ibu hamil dari pantangan-pantangan yang mereka yakini karena bila dilanggar akan mendapat musibah. Kemudian bagi wanita yang sedang hamil dianjurkan untuk membaca Al-Qur'an khususnya surat Yusuf supaya kelak anak yang hadir nanti memiliki ketampanan dan lembutnya sifat Nasbi Yusuf AS.

Kegiatan ini telah menjadi suatu bentuk anjuran yang berfungsi sebagai bentuk antisipasi terhadap kemungkinan yang 
tidak di inginkan. Makna mendalam yang terdapat pada kegiatan adalah bahwa sebagai manusia hendaklah kita berperilaku sesuai dengan kodrat kita sebagai makhluk yang mulia. Diciptakan oleh Allah Swt. dalam bentuk yang sebaik-baiknya agar menjadi sesuatu yang baik juga di dunia.

\section{Tradisi Budaya Nuak Ketan}

Budaya ini biasanya dilaksanakan ketika ibu yang sedang mengandung memasuki usia kehamilan 7 bulan. Nuak Ketan ini bertujuan memberitahukan pada masyarakat bahwa sang ibu telah mengandung selama 7 bulan yang mungkin akan membutuhkan bantuan. Kegiatan ini juga bertujuan agar anak yang berada dalam kandungan sehat dan lahir dengan selamat.

Dalam tradisi ini, keluarga ibu yang hamil memasak ketan putih yang disajikan di piring. Selanjutnya ketan tersebut ditaburi kelapa yang telah diolah dengan gula merah (kelapa inti). Setelah sajian ketan selesai diproses, selanjutnya dibagikan kepada para keluarga dan tetangga yang berada disekitar rumah. Ketan ini juga dibagikan kepada orang yang akan membantu persalinan ibu yang hamil. Orang yang akan membantu persalinan tersebut disebut dukun beranak oleh masyarakat Seberang Kota Jambi.

Pada perkembangannya, Nuak Ketan ini tidak melibatkan lagi dukun beranak, karena pada saat ini orang yang melahiran langsung dibawa kerumah sakit atau persalinan agar ditangani oleh dokter ahli. Selanjutnya hanya ketan yang masih digunakan dan dibagikan kepada keluarga dan tetangga. Meskipun mengalami perubahan dalam prakteknya, tujuan dari prosesi tetap sama supaya anak yang berada dalam kandungan tetap sehat dan kelak lahir dengan selamat. Tradisi ini sebagai bentuk rasa syukur kepada Allah Swt. yang telah menjaga kehidupan manusia yang sedang berlangsung di dunia ini. Tanpa ada campur tangan sang pencipta, manusia tidak akan memperoleh kehidupan yang di inginkannya.

\section{Tradisi Nyukur Bayi}

Nyukur bayi merupakan kegiatan mencukur rambut bayi yang dilakukan setelah sang bayi yang berumur tujuh hari pada acara aqiqah dengan menyembeli hewan yang berupa 2 ekor 
kambing bagi anak laki-laki dan 1 ekor kambing bagi anak perempuan. Prosesi acara ini dengan dibacakan marhaban, berjanzi dan doa kepada Allah Swt. serta Nabi Muhammad Saw. oleh para ulama. Sedangkan yang mencuku rambut bayi adalah tujuh orang yang dianggap penting seperti para tokoh agama serta masrakrakat. Tujuan dari acara mencukur rambut bayi ini sebagai bentuk pengharapan dan keinginan orang tua pada anak ini agar menjadi anak yang soleh.

Nyukur merupakan prosesi yang selalu dilakukan ketika orang tua melakukan aqiqah kepada anaknya. Kegiatan ini menjadi ucapan puji dan syukur kepada Allah Swt. yang telah memberikan kesehatan kepada sanga anak. Dengan adanya Allah Swt. di setiap sendi kehidupan anak, akan membuat anak menjadi sosok yang baik nantinya, kelak akan menjadi anak yang soleh dan berbakti pada orang tuannya.

\section{Tradisi Budaya Ziarah Kubur}

Ziarah kubur adalah sebuah kegiatan mengunjungi makam orang yang telah meninggal dunia untuk membersikan kondisi makam dari rerumputan serta kemudian memanjatkan doa kepada yang telah meninggal agar tenang dialam kubur. Tujuan dari kegiatan ini sebagai bentuk cara untuk mendokan sanak saudara yang telah meninggal agar ditempatkan di surga oleh Allah SWT..

Pada awal mulanya kegiatan ini dilaksanakan secara beramai-ramai satu desa dan kelurahan sesuai dengan waktu yang telah disepakati bersama. Ziarah kubur pada masyarakat Seberang Kota Jambi dilaksanakan dua kali dalam setahun, yaitu pada har-hari mendekati bulan Ramadhan dan pada hari Raya Idul Fitri yang kedua. Dalam ziarah ini dilakukan pembacaan Yasin, Tahlil dan doa agar arwah kaum muslimin yang meninggal ditempatkan di surga oleh Allah SWT..

Ziarah kubur masyarakat biasanya juga membersihkan rumput-rumput liar yang tumbuh disekitar pemakaman. Ziarah kubur juga menjadi ajang mengingat kembali sosok yang dimakamkan ketika dulu masih hidup didunia. Kegiatan ini menjadi tradisi yang dilestarikan oleh masyarakat Seberang Kota Jambi 
karena memiliki nilai-nilai positif berupa adanya persatuan dan kesatuan antar sesama masyarakat setempat.

\section{Wujud Seni Budaya Keagamaan}

\section{Arab Melayu Seberang Kota Jambi}

Seni adalah hasil karya manusia atau hasil ungkapan jiwa manusia. Tetapi, tidak semua hasil ciptaan manusia bisa disebut seni atau dikategorikan sebagai seni karena memang tidak semua hasil karya manusia dimaksudkan sebagai karya seni. ${ }^{25}$ Sebuah karya cipta manusia mendapat predikat seni jika dengan sengaja dibuat untuk dinikmati atau diapresiasi oleh masyarakat. ${ }^{26}$ Budaya kaagamaan Arab Melayu Seberang Kota Jambi memiliki berbagai seni yang terhubung langsung dalam kehidupan masyarakat.

Seni budaya keagaamaan Arab Melayu Seberang Kota Jambi juga hanya bisa dilakukan masyarakat Seberang Kota Jambi. Hal ini juga mendakan bahwa kedudukan mereka berbeda dan mempunyai keunikan tersendiri, sehingga menjadi kebiasaan masyarakatnya. Namun seiring dengan perkembangan tradisi ini telah dilakukan oleh semua masyarakat Seberang Kota Jambi. Seni budaya kaagamaan Arab Melayu Seberang Kota Jambi adalah musik Gambus, tari Zapin, tari Dana Syarah dan Hadrah.

\section{Musik Gambus}

Musik Gambus adalah sebuah lantunan musik yang diiringi oleh alat musik yang bernama Gambus. Alat musik Gambus sendiri dimainkan dengan cara dipetik. Alat musik ini sendiri berasal dari Timur Tengah yang dibawah oleh para pedagang dalam pelayarannya. Selanjutnya musik Gambus ini diterima oleh masyarakat setempat dan menjadi karya budaya daerah. ${ }^{27}$ Pada kawasan Seberang Kota Jambi, musik Gambus awalnya

${ }^{25}$ Moh Rondhi, "Apresiasi Seni dalam Konteks Pendidikan Seni," Imajinasi : Jurnal Seni XI (January 2017): 10.

${ }^{26}$ Desmond, K.K, Ideas About Art, 2011th ed. (UK: Wiley Blckwell, n.d.), 40 .

${ }^{27}$ Rio Eka Putra, "Fungsi Ansambel Musik Gambus Dalam Kehidupan Masyarakat Riau," Besaung : Jurnal Seni Desain Dan Budaya 1 (September 1, 2016): 19. 
hanya dimainkan oleh para pedagang Arab ketika berada di kawasan ini. Selanjutnya, musik gambus ini menjadi hiburan dari masyarakat setempat yang menyaksikan para pedagang Arab memainkan.

Seiring waktu berjalan, musik gambus ini menyatu dengan kehidupan masyarakat setempat, bersamaan dengan akulturasi kebudayaan pedagang (Arab) dengan masyarakat setempat (Melayu). Terjadinya perkawinan antara pedagang dengan masyarakat setempat juga berperan terhadap musik Gambus di kawasan seberang Kota Jambi. Karena dalam pesta perkawinan, musik gambus menjadi musik yang mengiringi acara. Musik Gambus yang berada di kawasan Seberang Kota Jambi ini memiliki keunikan sendiri dengan menambahkan cengkok Melayu dalam lantuannya.

Musik Gambus masyarakat Seberang Kota Jambi sering ditampilkan pada acara-acara perayaan seperti pernikahan, kendurian, sunatan dan lainnya. Musik gambus masyarakat Seberang Kota Jambi tidak kalah populer dari musik gambus daerah lainnya karena memiliki ciri khas serta keunikannya sendiri berupa perpaduan unsur budaya Arab dan Melayu. Alunan musik Gambus dengan lantunan bahasa Arab yang dipadukan dengan cengkok Melayu menjadi keunikan tersendiri.

\section{Tari Zapin}

Tari menjadi bagan dari cabang seni dalam ungkapannya mengemukakan bahasa gerak tubuh. ${ }^{28}$ Tari Zapin adalah tari yang dimiliki masyarakat muslim di Nusantara. Tari ini dapat ditemukan pada masyarakat di daerah pesisir atau maritim nusantara, baik Zapin Arab maupun Zapin Melayu. ${ }^{29}$ Pada masyarakat Seberang Kota Jambi, tari Zapin telah menjadi bagian dari budaya daerahnya yang berkembang dari etnis keturunan Arab.

Zapin sendiri merupakan sebuah bahasa Arab yang berarti gerakan kaki cepat mengikuti rentak pukulan dan irama. Tari

${ }^{28}$ Kuswarsantyo, "Pelajaran Tari : Image Dan Kontribusinya Terhadap Pembentukan Karakter Anak," Jurnal Seni Tari 3, no. 1 (2012): 17.

${ }^{29}$ Anis, Zapin Melayu Di Nusantara, 2000th ed. (Johor Baru: Yayasan Warisan Johor, n.d.), 5. 
Zapin yang berasal dari daerah Arab Selatan ini diwariskan oleh nenek moyang etniks Arab yang digunakan sebagai sarana untuk menyebarkan agama Islam melalui syair lagu-lagu Zapin. Pada awalnya tarian ini ditujukan sebagai hiburan kalangan raja-raja yang dibawa oleh pedagang-pedagang diawal abad ke-16 M.

Kini tarian Zapin merupakan tari pergaulan muda-mudi yag bersifat hiburan dengan diiringi dua alat utama yaitu gambus dan tabuh (mawas). Awal mulanya tarian ini hanya dilakukan oleh pria, namun sekarang wanita juga boleh menarikannya. Kemudian, kini dapat pula ditarikan oleh pria bersama wanita. Tarian ini ditampilkan oleh enam orang yang semua penarinya berpasangan antara laki-laki dan perempuan dengan durasi tarian ini berkisar 8 sampai 12 menit.

Kostum yang digunakan biasanya berbusana Arab (Gamis). Dalam perkembangannya para penari mulai mengenakan teluk belango dan peci putih serta peci Hitam. Dalam perkembangannya, tari Zapin telah banyak dikombinasikan dengan gerakan tarian lokal setempat sehingga gerakannya tidak lagi murni dari Arab.

\section{Tari Dana Syarah}

Tari Dana Syarah berasal dari Timur-Tengah yang diterima oleh masyarakat Seberang Kota Jambi kemudian bercampur dengan budaya setempat. Tari Dana dan Tari Zapin merupakan tari-tarian yang berasal dari Arab dan berkembang setelah para ulama melakukan perjalanan ke daerah Teluk Persia dan Madinah. Setelah melewati Teluk Persia mereka menuruskan perjalanan ke Jazirah Arab karena letak Jazirah Arab berdekatan dengan India.

Kemudian terjadilah proses percampuran kebudayaan Islam dengan kebudayaan India. Kebudayaan yang telah mengalami proses percampuran tersebut ikut bersama para pedagang ke nusantara. Kebudayaan yang dibawa oleh para pedagang ini dapat berupa tarian dan musik. Selain tari Zapin dan tari Dana Syarah juga menjadi salah satu budaya yang dibawa ke nusantara, khusunya ke daerah Seberang Kota Jambi.

Tari Dana Syarah terdiri dari dua bagian, yakni tarian dengan iringan lagu Dana dan tarian dengan iringan lagu Syarah. 
Jika ditinjau dari asal katanya, Syarah berarti suatu bentuk sya' ir pujian terhadap Allah Swt. dan Nabi Muhammad Saw. Jadi, tari Dana Syarah adalah tarian yang berfungsi untuk mengungkapkan rasa syukur kepada sang pencipta Allah Swt. dan baginda rasul Nabi Muhammad Saw. lewat gerak tari yang diiringi dengan lagu. Pada awalnya tari ini ditampilkan dalam kelompok pria dikalangan terbatas seperti keluarga-keluarga keturunan Arab. Kemudian pada perkembangannya tari Dana Syarah menjadi tari pergaulan yang dibawakan secara berpasangan antara putra-putri dikalangan masayarakta yang lebih luas.

\section{Hadrah (Kompangan)}

Hadrah atau yang disebut juga musik rebana merupakan bentuk tradisi kesenian dengan bernuansa Islam yang kental pada masyarakat Seberang Kota Jambi. Hadrah biasanya dimainkan untuk mengiringi pengantin, cukuran bayi, dan acara kegamaan lainnya. Pada awalnya Hadrah digunakan sebagai bentuk media penyebaran atau mensyiarkan agama Islam. Seiring berkembangannya zaman, kesenian ini mulai digunakan pada berbagai acara seperti Maulid Nabi, arak-arakan pernikahan, cukuran dan penyambutan tamu agung.

Kesenian Hadrah sendiri memiliki filosofi tentang keselarasan antara seni dan agama. Hadrah merupakan seni yang menjadi media dalam penyeberan agama Islam, menghubungkan dan menselaraskan penyebaran agama Islam lewat seni. Hadrah menjadi kesenian yang bernuansa Islam dengan menampilkan iringan alat musik rebana bersama lantunan syair serta pujian terhadap Allah Swt. dan nabi Muhammad Saw. Hadrah bisa menjadi sarana alat penyebar agama Islam yang memuat nilai budaya. Hadrah selain berfugsi sebagai kesenian, juga bisa menjadi sarana untuk bersilaturahmi dan menjalin keakraban antar sesama warga. Karena terjadi proses interaksi dan komunikasai ketika kegiatan Hardah ini berlangsung. 


\section{Nilai-Nilai Luhur Budaya Keagamaan Arab Melayu Seberang Kota Jambi}

Nilai merupakan hakikat suatu hal yang menyebabkan hal itu pantas dikejar oleh manusia. ${ }^{30}$ Nilai adalah sesuatu yang menarik bagi kita, sesuatu yang dicari, sesuatu yang menyenangkan, sesautu yang disukai dan di inginkan. ${ }^{31}$ Pengalaman dan penghayatan nilai itu melibatkan hati, hati nurani serta budi. Hati menangkap nilai dengan merasakannya dan budi menangkap nilai dengan memahami dan menyadarinya. ${ }^{32}$

Nilai dan budaya menjadi satu kesatuan di dalam kehidupan masyarakat. Dalam budaya terdapat nilai-nilai yang senantiasa diwariskan dari generas ke generasi. Terus melekat kuat dan mejadi ciri khas sekaligus identitas dari suatu kelompok tertentu. Budaya berperan sentral dan mendasar sebagai tatanan kehidupan suatu masyarakat, karena suatu masyarakat akan menjadi besar apabila memiliki nilai-nilai luhur budaya yang telah mengakar dalam sendi kehidupannya.

Budaya Arab Melayu Seberang Kota Jambi memuat niainilai luhur dalam budayanya. Nilai-nilai budaya keagamaan Arab Melayu Seberang Kota Jambi ini berupa nilai budaya, nilai agama, nilai karakter, nilai kekeluargaan dan nilai seni.

\section{Nilai Budaya}

Budaya Keagamaan Arab Melayu yang terdapat pada masyarakat Seberang Kota Jambi memiliki nilai-nilai yang telah diakui bersama, tertanam dalam diri masyarakat setempat yang dihasilkan dari tradisi atau kebiasan serta simbol-simbol karakteristik tertentu sampai selanjutnya menjadi pedoman perilaku masyarakatnya. Nilai ini telah tertanam pada masyarakat Seberang Kota Jambi dijadikan sebagai pedoman dan petunjuk untuk berperilaku di kehidupan sehari-hari.

\footnotetext{
${ }^{30}$ Kamrani Buseri, Antologi Pendidikan Islam dan Dakwah : Pemikiran Teoritis, 2003rd ed. (Yogyakarta : UII Press., n.d.), 78.

${ }^{31}$ Subur, "Telaah Tentang Model Pembelajaran," Jurnal Insania 12 (April 1, 2007): 2.

${ }^{32}$ A Atmadi and Setyaninggsih, Transformasih Pendidikan Memasuki Milenium Ketiga, 2000th ed. (Yogyakarta: Kanisius, n.d.), 72.
} 
Adanya budaya keagamaan Arab Melayu membuat generasi muda sadar bahwa unsur dari kemajuan. Dapat dilihat dari kegiatan gotong royong masyarakat Seberang Kota Jambi ketika menolong warga yang melaksanakan sebuah acara hajatan dikenal dengan kegiatan manggung. Pelaksanaan tradisi Burdah, Nyukur bayi, Makan besamo dan Nuak Ketan. Budaya keagamaan Arab Melayu ini menjadi contoh untuk membangkitkan budaya lain yang berada diwilayah lain agar setiap wilayah memiliki budaya dan keunikan masing-masing. Nilai budaya menjadi stimulus bagi masyarakat mencapai tujuan dalam hidupnya.

\section{Nilai Agama}

Nilai budaya keagamaan Arab Melayu Seberang Kota Jambi dapat dilihat dari budaya keIslamannya, sehingga nilai agama ini mejadi nilai yang paling terlihat dari yang lainnya. Agama menjadi pedoman hidup bagi masyarakat Seberang Kota Jambi. ini memperlihatkan bahwa ajaran agama dalam suatu masyarakat didasarkan pada peraturan yang dibuat, sedangkan peraturan harus berpijak pada kita Al-Qur'an. Kebanyakan dari setiap budaya keagamaan Arab Melayu di masyarakat Seberang Kota Jambi memuat ajaran agama yang tinggi.

Nilai agama pada masyarakat Seberang Kota Jambi dapat dilihat dari ketaatan masyarakat dalam beribadah, peringatan Assyura dan Nisfu Sya'ban. Disetiap sendi-sendi masyarakat Seberang Kota Jambi selalu bernafaskan dengan ajaran Islam. Bagi mereka Islam sudah menjadi bagian dari kehidupan mereka selain menjadi agama yang dianut.

\section{Nilai Karakter}

Nilai karakter pada budaya keagaamaan Arab Melayu Seberang Kota Jambi dapat terlihat pada pola perilaku kesehariannya. Kegiatan makan besamo yang sering mayarakat laksanakan juga mencerminkan bahwa kebersamaan menjadi hal yang utama dalam pergaulan. Masyarakat juga lebih mengutamakan musyawarah dalam menghadapi segala problem dan masalah yang sering terjadi. Memperlihatkan bahwa masyarakat Seberang Kota Jambi memiliki karakter yang baik budinya. 
Masyarakat Seberang Kota Jambi telah hidup bersama dari pulahan tahun yang lalu dengan tetap menjaga keharmonisan wilayahnya. Ini menandakan adanya keterikatan antara seluruh elemen yang terdapat pada kawasan ini. Perbedaan menjadikan keunikan dari yang mereka tampilkan dan kebersamaan menjadi penyatu mereka dalam menjalani kehidupan.

\section{Nilai Kekeluargaan}

Nilai kekeluargaan pada budaya keagaaman Arab Melayu Seberang Kota Jambi tercerminkan pada kegiatan manggung yang bertujuan membantu orang yang sedang mempunya acara atau hajatan. Kemudian ziarah kubur bersama kerabat dan keluarga ke pemakaman yang selaian tujuannya membersikan kuburan, juga mempererat tali silaturahmi pada saat membersihkan makam tersebut.

Dari pemaparan di atas bisa didapat gambaran nilai kekeluargaan budaya keagamaan Arab Melayu Seberang Kota Jambi. Nilai ini bisa diwariskan melalui berbagai kegiatan di masyarakat, termsauk dalam kegiatan formal dan non formal. Kegiatan formal seperti kehidupan bersama pada santri yang bersekolah di pondok pesantren yang terdapat di Seberang Kota Jambi. Kegiatan non-formal seperti pada kegiatan kendurian dan syukuran yang membutuhkan kerjasama dalam menyelegarakannya.

\section{Nilai Seni}

Buadaya Keagamaan Arab Melayu memiliki nilai seni yang didasari ajaran Islam. Seni yang terdapat pada masyarakat Seberang Kota Jambi adalah seni musik Gambus, tari Zapin dan tari Dana Syarah. Tari Zapin memiliki fungsi sebagai salah satu tari pergaulan muda-mudi masyarakat Seberang Kota Jambi. Sedagkan tari Dana Syarah digunakan sebagai hiburan dan pergaulan diantara Habib, Sayyid dan para pemuka agama lainnya. Musik gambus dalam hal ini berfungsi sebagai pengiring tari Zapin dan tari Dana Syarah.

Budaya keagamaan Arab Melayu Seberang Kota Jambi memperlihatkan bagaimana budaya dapat berdampingan dengan ajaran agama Islam. Karena pada hakikatnya seni menampilkan suatu keindahan yang diciptkan oleh manusia. Sementara itu, 
agama Islam merupakan tuntunan bagi manusia pada Allah Swt. dalam menjalani kehidupan didunia. Melalui budaya keagamaan Arab Melayu manusia dapat mengespresikan keindahan budaya yang merujuk pada agama Islam.

\section{PENUTUP}

Budaya keagamaan Arab Melayu Seberang Kota Jambi telah menjadi cerminan hidup dari masyarakat seberang Kota Jambi. Budaya Arab Melayu Seberang Kota Jambi menghasilkan budaya yang berjenis immaterial dengan wujud kegiatan peringatan Assyura, perayaaan Nis'fu Syaban, Burdah, Nginau, Nuak Ketan, Nyukur bayi dan Ziarah Kubur. Selain itu, dapat juga dilihat melalui pertunjukan musik Gambus, tari Zapin, tari Dana Syarah dan Hadrah. Budaya keagamaan Arab Melayu Seberang Kota Jambi memuat nilai-nilai budaya, agama, karakter, kekeluarga dan seni dalam seluruh kegiatannya.

Budaya keagamaan Arab Melayu Seberang Kota Jambi memuat nilai-nilai yang terdiri dari, pertama, nilai budaya pada kegiatan Burdah, Nyukur Bayi, Makan Besamo dan Nuak Ketan, kedua, nilai agama pada pelaksanaan peringatan hari Assyura dan Nisfu Sya'ban, ketiga, nilai karakter pada kegiatan makan besamo, keempat, nilai kekeluargaan pada kegiatan ziarah kubur dan, kelima, nilai seni pada pagelaran musik Gambus, tari Zapin dan tari Dana Syarah.

Budaya keagamaan Arab Melayu Seberang Kota Jambi menjadi contoh bentuk dari budaya daerah yang terdapat di Indonesia. Budaya ini juga dapat dikenal oleh khalayak ramai sebagai bagian dari budaya daerah yang menjadi kesatuan dalam kebudayaan nasional. Budaya keagamaan Arab Melayu Seberang Kota Jambi juga mnjadi bentuk pemertahan warisan budaya leluhur agar tidak punah ditelan zaman. Kegiatan, tradisi dan seni yang berlangsung pada budaya ini sebagai upaya mempertahankan ciri atau identitas dari suatu masyarakat di suatu daerah. 


\section{DAFTAR PUSTAKA}

\section{Buku}

A Atmadi and Setyaninggsih. Transformasih Pendidikan Memasuki Milenium Ketiga. 2000th ed. Yogyakarta: Kanisius, n.d.

Anis. Zapin Melayu Di Nusantara. 2000th ed. Johor Baru: Yayasan Warisan Johor, n.d.

Buseri, Kamrani. Antologi Pendidikan Islam dan Dakwah: Pemikiran Teoritis. 2003rd ed. Yogyakarta : UII Press., n.d.

Desmond, K.K. Ideas About Art. 2011th ed. UK: Wiley Blckwell, n.d.

Djumransjah, HM. Pendidikan Islam Menggali "Tradisi" Mengukuhkan Eksistensi. Jakarta : P3M, 1998.

Katalog. Museum Gentala Arasy. 2019th ed. Jambi: Pemeritahan Provinsi Jambi Dinas Kebudayaan dan Pariwisata Museum Sigenjai, n.d.

Koentjaraningrat. Pengantar Antropologi II. 1998th ed. Jakarta: Rineka Cipta, n.d.

Marfu'ah. Mengenal Hari-Hari Besar Islam. 2010th ed. Semarang: Alprin, n.d.

Mursa. Kamus Ilmu Jiwa Dan Pendidikan. 1980th ed. Bandung: Al-Ma'arif, n.d.

Poesponegoro. Sejarah Nasional Indonesia: Zaman Pertumbuhan dan Perkembangan Kerajaan Islam Di Indonesia. 1990th ed. Jakarta: Balai Pustaka, n.d.

Spradley James. Metode Etnografi. 2007th ed. Yogyakarta, n.d.

Tasmuji. Ilmu Alamiah Dasar, Ilmu Sosial Dasar, Ilmu Budaya Dasar. 2011th ed. Surabaya: IAIN Sunan Ampel Press, n.d.

W.J.S. Poerwadarminta. Kamus Umum Bahasa Indonesia. 1991st ed. Jakarta: PN Balai Pustaka, n.d.

Zumratus. Menggapai Berkah Di Bulan-Bulan Hijriyah. 2015th ed. Jakarta: Pustaka Al-Kautsar, n.d. 


\section{Jurnal Ilmiah}

Alfain Nur Mustawhisin, Rully Putri Nirmala Puji, and Wiwin Hartanto. "Sejarah Kebudayaan : Hasil Budaya Material Dan Non Material Akibat Adanya Pengaruh Islam Di Nusantara." Bakaba: Jurnal Sejarah Kebudayaan Dan Kependidikan 8 (June 2019) : 1.

Ainur, Rofiq. "Tradisi Slametan Jawa Dalam Perspektif Pendidikan Islam." Jurnal Pendidikan Islam 15, no. 2 (September 2, 2019) : 96.

Huda, Khairul. "Islam Melayu Dalam Pusaran Sejarah : Sebuah Transformasi Kebudayaan Melayu Nusantara." Toleransi : Media Komunikasi Umat Beragama 8, no. 1 (June 2016) : 79.

Kamarusdiana. "Studi Etnografi Dalam Kerangka Masyarakat Dan Budaya." Salam: Jurnal Sosial dan Budaya Syar-i 6, no. 2 (March 22, 2019) : 28.

Khairuddin, Ahmad. Asyura: Antara Doktrin, Historis Dan Antropologis Perspektif Dakwah Pencerahan. Vol. 3. 5. Jurnal Al-Hiwar, $2015: 1$.

Kuswarsantyo. "Pelajaran Tari : Image Dan Kontribusinya Terhadap Pembentukan Karakter Anak." Jurnal Seni Tari 3, no. 1 (2012) :17.

Lilis Suciandi. "Peranan Arab Melayu Dalam Pengembangan Islam Di Kota Jambi Awal Abad XX" Istoria : Jurnal Pendidikan Sejarah UNBARI. Vol 3 No 2 September 2019 (September 2, 2019): 2.

Putra, Rio Eka. "Fungsi Ansambel Musik Gambus dalam Kehidupan Masyarakat Riau." Besaung : Jurnal Seni Desain Dan Budaya 1 (September 1, 2016) : 7.

Rondhi, Moh. "Apresiasi Seni Dalam Konteks Pendidikan Seni." Imajinasi : Jurnal Seni XI (January 2017) : 1.

Ryan and Endang. "Pergeseran Nila-nilai Budaya Pada Suku Bonai Darussalam Kabupaten Rokan Hulu Provinsi Riau. "Jurnal Humanika 23, no. 1 (2016) : 19. 
Subur. "Telaah Tentang Model Pembelajaran." Jurnal Insania 12 (April 1, 2007): 3-16

Ulfah, Siti Mariah. "Perukunan Tsamaratul Insan Dan Perannya Dalam Menghadapi Perubahan Sosial Budaya Di Provinsi Jambi.” Buletin Al-Turas 26 (January 2020) : 1. 


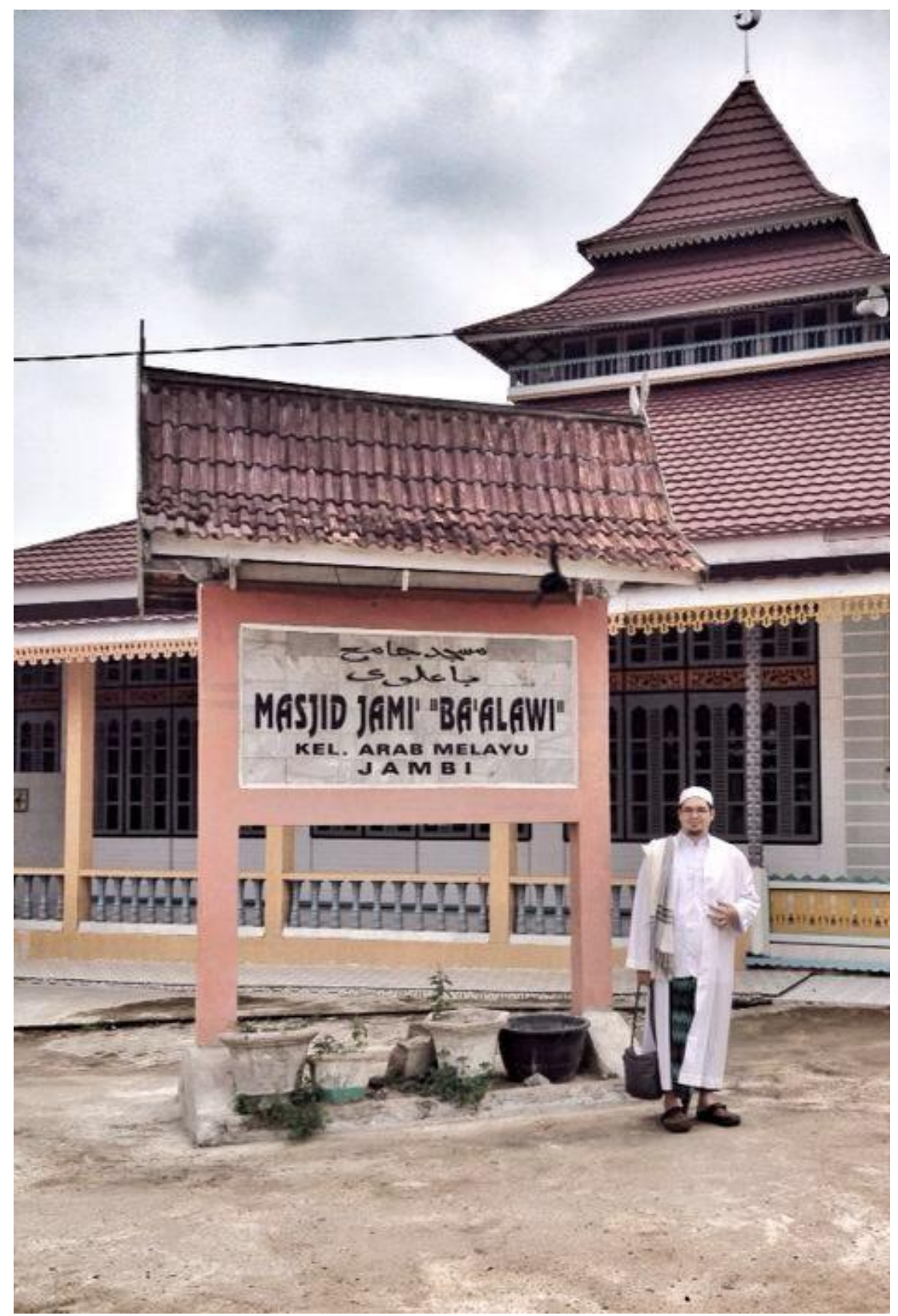

Sumber: Dokumentasi Akun Twitter Habib Jindan Novel @ habibjindan

Gambar. 1

Masjid Jami’ Ba'alawi Kota Jambi 